\title{
Assessment of Corrosion Inhibiting Efficiency of Microbes Induced Concrete
}

\author{
V Srinivasa Reddy $^{1}$, Polina VVSSSR Krishna ${ }^{2}$, G Sai Karthik $^{3}$, S Shrihari ${ }^{4}$ \\ ${ }^{1}$ Professor of Civil Engineering, GRIET, Hyderabad, India. \\ ${ }^{2}$ Assistant Professor of Civil Engineering, GRIET, Hyderabad, India. \\ ${ }^{3}$ M.Tech (Structural Engineering), Department of Civil Engineering, GRIET, Hyderabad, India \\ ${ }^{4}$ Professor of Civil Engineering, VJIT, Hyderabad, India.
}

\begin{abstract}
The study present in this paper reveals the corrosion inhibiting efficiency of M25 grade concrete induced with Sporosarcina pasteurii bacteria. The accelerated corrosion induced crack method is applied on reinforced bacterial concrete which is the modified philosophy of constant voltage technique. In the current investigation, for different cover thicknesses considered, total time required for charge passed until full longitudinal crack occurs along the cover thickness due to corrosion of steel reinforcement in concrete specimens are measured using which Charge Deterioration Factors (ChDFs) are evaluated for bacterial reinforced concrete beams made with various cell concentrations of Sporosarcina pasteurii bacteria. It was established that beams made with cell concentration of $10^{5}$ cells $/ \mathrm{ml}$ of mixing water offers superior corrosion inhibition ability as time taken to form full length longitudinal crack is more than in other beams made with $10^{3}$ cells $/ \mathrm{ml}, 10^{4} \mathrm{cells} / \mathrm{ml}$ and $10^{6}$ cells $/ \mathrm{ml}$ cell concentration of bacteria chosen for the study.
\end{abstract}

\section{Introduction}

Concrete is inherently offers better resistance to corrosion of rebars embedded inside it except in very harsh saline environments. If the concrete is induced with Sporosarcina pasteurii bacteria during mixing stage, will contribute to more enhanced corrosion resistance capacity due to biomineralization mechanism during microbial metabolic activity. In this paper, an attempt has been made to measure the corrosion resistance in bacterial concrete specimens with four different thicknesses of covers using the impressed constant voltage technique. It is very labor intensive and time taking experiment with a fabricated setup. It is observed that the incorporation of bacteria into concrete helps to protect concrete against the chlorideinduced corrosion of steel reinforcement by reducing its permeability, particularly for chloride-ion transportation, and increasing the impermeability of the concrete considerably.

\section{Methodology}

Various bacterial cell count of Sporosarcina pasteurii used are $10^{3}$ cells $/ \mathrm{ml}, 10^{4}$ cells $/ \mathrm{ml}, 10^{5}$ cells $/ \mathrm{ml}$ and $10^{6} \mathrm{cells} / \mathrm{ml}$. The nutrients used for the growth and cultivation of bacterial culture comprises of urea $(20 \mathrm{~g} / \mathrm{l})$, sodium bicarbonate $(2.12 \mathrm{~g} / \mathrm{l})$, ammonia chloride $(10 \mathrm{~g} / \mathrm{l})$ and calcium chloride $(25 \mathrm{~g} / \mathrm{l})$.
Sporosarcina pasteurii is an alkaliphilic soil bacterium is introduced into concrete in suspension during mixing. Microbiologically Induced calcite precipitation (Biomineralization) is the process in which Sporosarcina pasteurii releases urease enzyme which hydrolyze the urea nutrient to form carbon dioxide and ammonia. Carbon dioxide reacts with calcium nutrients to produce calcium carbonate minerals which will fill up the micro and macro pores present in the concrete arresting the continuous water paths present. Ammonia will help concrete to maintain its $\mathrm{pH}$ so that passive layer can be formed on rebars as protective surface layer.

A total of 10 beams of dimensions $150 \times 150 \times 500 \mathrm{~mm}$ are cast and tested after 28 days of normal curing. The beams have the reinforcement of $10 \mathrm{~mm}$ diameter HYSD bar at different effective covers ranging from $10 \mathrm{~mm}$ to $40 \mathrm{~mm}$ at all four corners of each beam.

\section{Accelerated Corrosion Test}

Due to the expansive nature of corrosion products in rebar concrete beams of M25 grade, corrosion-induced cracks are generated at the interface between the rebars and its surrounding concrete resulting in cracking and spalling of cover. To simulate this corrosion process in a typical seawater environment. The beam specimens were submerged into artificial sea water solution prepared in the 
laboratory as per ASTM D 1141 - 1998 (Sodium chloride $24.53 \mathrm{~g} / \mathrm{lit}$, Magnesium chloride $5.2 \mathrm{~g} / \mathrm{lit}$, Sodium sulphate $4.09 \mathrm{~g} /$ lit, Calcium chloride $1.16 \mathrm{~g} / \mathrm{lit}$, Potassium chloride $0.695 \mathrm{~g} / \mathrm{lit})$. The specimens were corroded using an electrochemical accelerated corrosion technique that involved keeping a constant voltage of $20 \mathrm{~V}$ through the specimens to accelerate the oxidation process in a $3.5 \%$ saline solution. When Steel rebars are corroded electrochemically eventually leads to the expansion of rebars inducing cracks in the cover of the concrete. Time taken to induce complete crack along the length of beam is computed to estimate the corrosion resistance ability of bacterial concrete. This test procedure is inspired from the standard ASTM G109. Corrosion in rebars can be artificially induced either by providing constant current through rebars or by keeping voltage constant. In this test the beams reinforced with $10 \mathrm{~mm}$ diameter rebars with different effective covers are casted as shown in Fig. below.

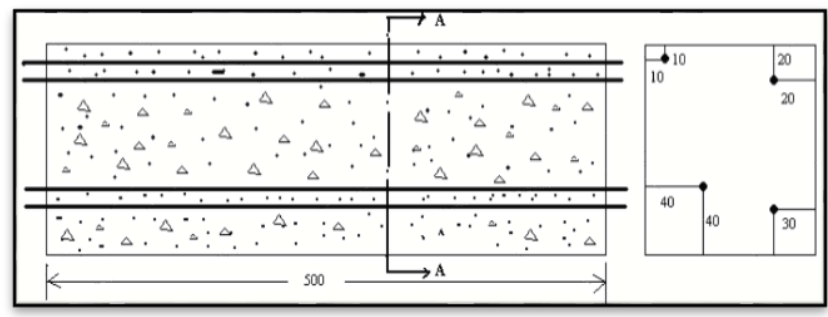

Fig.1. Schematic diagram of reinforced beam used for the test

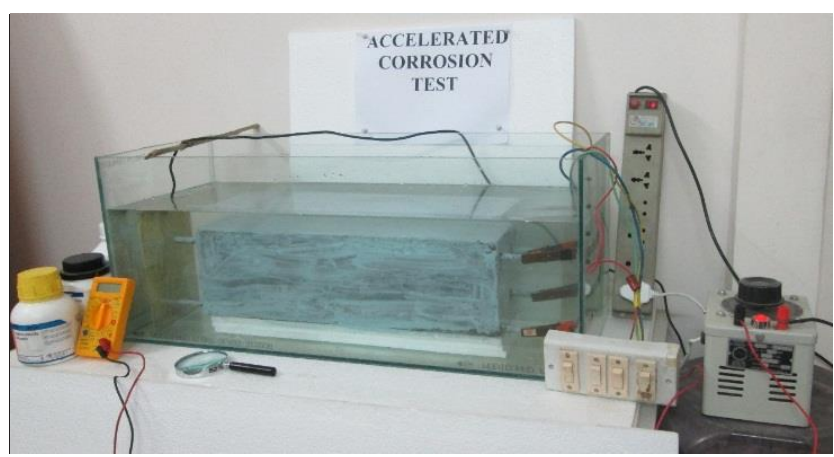

Fig. 2. Setup for the Accelerated Corrosion test

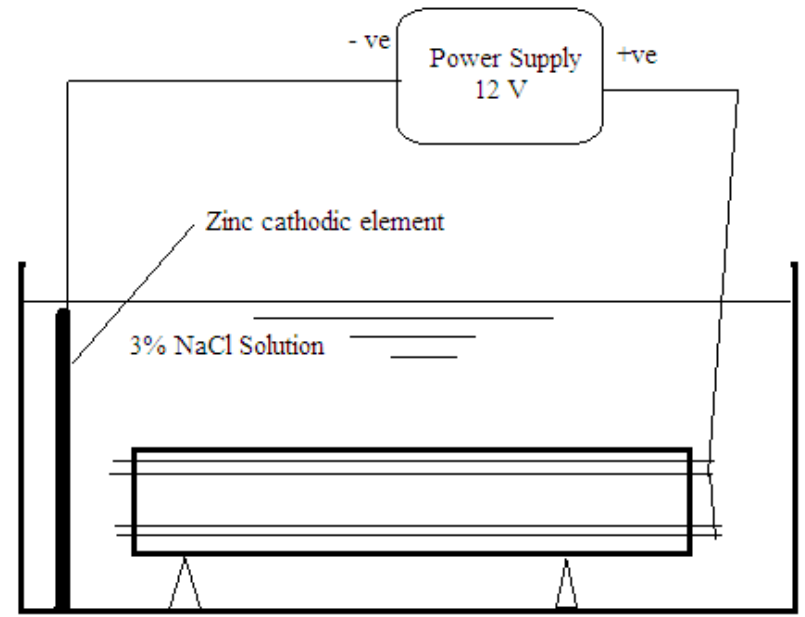

Fig. 3. Schematic diagram of Accelerated corrosion test setup

The test specimens concrete reinforced beams has different effective covers of $10 \mathrm{~mm}, 20 \mathrm{~mm}, 30 \mathrm{~mm}$ and $40 \mathrm{~mm}$ at all four corners. The test specimens are immersed in saline watered glass tub. All the extended rebars are connected to the power supply in parallel and anodic current is passed at a constant voltage of $20 \mathrm{~V}$. For every $12 \mathrm{hrs}$. interval, the half-cell potentials are recorded for all the rebars. Time and length of the crack along the beam was observed frequently till the crack is formed longitudinally $(500 \mathrm{~mm})$. The experimental set up is shown in Fig..

Inspired from ASTM C 666 - 1997, the Charge Deterioration Factors are evaluated for every 12 hours based on the relative charge.

Charge Deterioration Factor $(\mathrm{ChDF})=\mathrm{rCh}(\mathrm{N} / \mathrm{M})$

Where, $\mathrm{rCh}=$ Relative Charge $(\%)$

$\mathrm{N}=$ Time at which $\mathrm{ChDF}$ is to be evaluated.

$\mathrm{M}=$ Time taken for complete crack in reference reinforced beam

$\mathrm{B} 1=$ Normal M25 grade concrete reinforced beam $\mathrm{B} 2=\mathrm{M} 25$ grade bacterial concrete reinforced beam made with cell concentration of $10^{3}$ cells $/ \mathrm{ml}$

B3 $=$ M25 grade bacterial concrete reinforced beam made with cell concentration of $10^{4}$ cells $/ \mathrm{ml}$

B4 = M25 grade bacterial concrete reinforced beam made with cell concentration of $10^{5}$ cells $/ \mathrm{ml}$

B5 $=$ M25 grade bacterial concrete reinforced beam made with cell concentration of $10^{6}$ cells $/ \mathrm{ml}$

\section{Accelerated Corrosion Test Results}

Based on the experimental investigations, the test results are presented as follows-

The table 1 and Fig. 6 presents time taken for formation of full crack due corrosion along the length of beams for beams with various cells of bacteria and compared with beams without bacteria. Tables 2-5 presents relative charge $(\mathrm{rCh})$ and charge deterioration factors (ChDF) for various concrete cover thickness. 


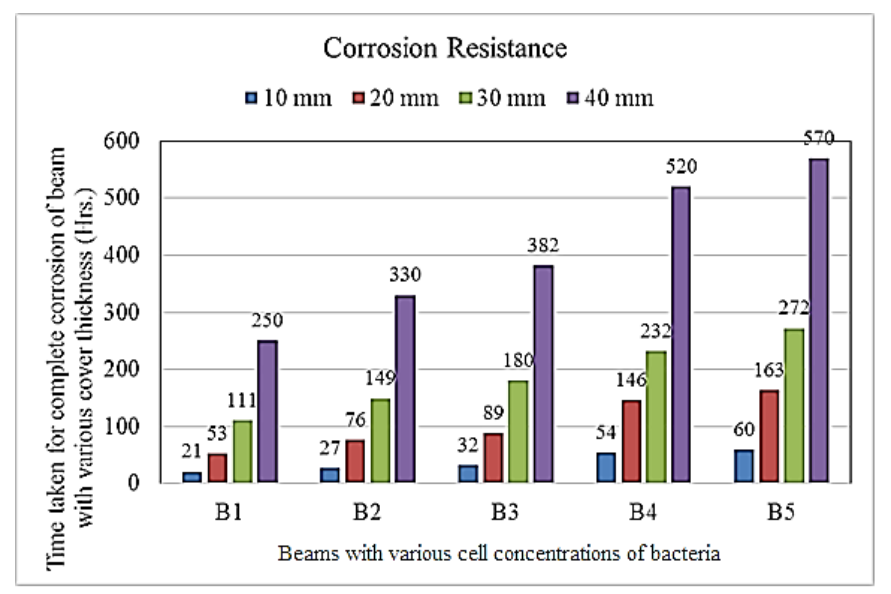

Fig. 4. Time taken for complete corrosion of rebar in beams with various concrete cover thickness (Time taken for full crack to occur longitudinally along the length of beams with different cover thickness)

Table 1. Relative Charge ( $\mathrm{rCh}$ ) and Charge Deterioration Factors (ChDF) for 10mm Cover

\begin{tabular}{|c|c|c|c|c|c|c|}
\hline \multirow{2}{*}{ Test duration } & \multirow{2}{*}{$\begin{array}{l}\text { Corrosion } \\
\text { indicators }\end{array}$} & \multicolumn{5}{|c|}{ Relative Charge (rCh) and Charge Deterioration Factors (ChDF) for 10mm effective cover } \\
\hline & & B1 & B2 & B3 & B4 & B5 \\
\hline \multirow{2}{*}{0} & $\mathrm{rCh}$ & 0.00 & 0.00 & 0.00 & 0.00 & 0.00 \\
\hline & $\mathrm{ChDF}$ & 0.00 & 0.00 & 0.00 & 0.00 & 0.00 \\
\hline \multirow{2}{*}{12} & $\mathrm{rCh}$ & 57.14 & 44.44 & 37.50 & 20.00 & 22.22 \\
\hline & $\mathrm{ChDF}$ & 1.20 & 0.94 & 0.79 & 0.42 & 0.47 \\
\hline \multirow{2}{*}{24} & $\mathrm{rCh}$ & 100.00 & 88.89 & 75.00 & 40.00 & 44.44 \\
\hline & $\mathrm{ChDF}$ & 4.81 & 3.74 & 3.16 & 1.68 & 1.87 \\
\hline \multirow{2}{*}{36} & $\mathrm{rCh}$ & & 100.00 & 100.00 & 60.00 & 66.67 \\
\hline & $\mathrm{ChDF}$ & & 8.42 & 7.11 & 3.79 & 4.21 \\
\hline \multirow{2}{*}{48} & $\mathrm{rCh}$ & & & & 80.00 & 88.89 \\
\hline & $\mathrm{ChDF}$ & & & & 6.74 & 7.49 \\
\hline \multirow{2}{*}{60} & $\mathrm{rCh}$ & & & & 100.00 & 100.00 \\
\hline & $\mathrm{ChDF}$ & & & & 10.53 & 11.70 \\
\hline
\end{tabular}

Table 2. Relative Charge and Charge Deterioration Factors for $20 \mathrm{~mm}$ Cover

\begin{tabular}{|c|c|c|c|c|c|c|}
\hline \multirow{2}{*}{ Test duration } & \multirow{2}{*}{$\begin{array}{l}\text { Corrosion } \\
\text { indicators }\end{array}$} & \multicolumn{5}{|c|}{ Relative Charge (rCh) and Charge Deterioration Factors (ChDF) for $20 \mathrm{~mm}$ Effective Cover } \\
\hline & & B1 & B2 & B3 & B4 & B5 \\
\hline \multirow{2}{*}{0} & $\mathrm{rCh}$ & 0.00 & 0.00 & 0.00 & 0.00 & 0.00 \\
\hline & $\mathrm{ChDF}$ & 0.00 & 0.00 & 0.00 & 0.00 & 0.00 \\
\hline \multirow{2}{*}{12} & $\mathrm{rCh}$ & 22.64 & 15.79 & 13.48 & 7.36 & 8.22 \\
\hline & ChDF & 0.48 & 0.33 & 0.28 & 0.15 & 0.17 \\
\hline \multirow{2}{*}{24} & $\mathrm{rCh}$ & 45.28 & 31.58 & 26.97 & 14.72 & 16.44 \\
\hline & ChDF & 1.91 & 1.33 & 1.14 & 0.62 & 0.69 \\
\hline \multirow{2}{*}{36} & $\mathrm{rCh}$ & 67.92 & 47.37 & 40.45 & 22.09 & 24.66 \\
\hline & ChDF & 4.29 & 2.99 & 2.55 & 1.39 & 1.56 \\
\hline \multirow{2}{*}{48} & $\mathrm{rCh}$ & 90.57 & 63.16 & 53.93 & 29.45 & 32.88 \\
\hline & ChDF & 7.63 & 5.32 & 4.54 & 2.48 & 2.77 \\
\hline \multirow{2}{*}{60} & $\mathrm{rCh}$ & 100.00 & 78.95 & 67.42 & 36.81 & 41.10 \\
\hline & $\mathrm{ChDF}$ & 11.92 & 8.31 & 7.10 & 3.87 & 4.33 \\
\hline \multirow{2}{*}{72} & $\mathrm{rCh}$ & & 94.74 & 80.90 & 44.17 & 49.32 \\
\hline & ChDF & & 11.97 & 10.22 & 5.58 & 6.23 \\
\hline \multirow{2}{*}{84} & $\mathrm{rCh}$ & & 100.00 & 94.38 & 51.53 & 57.53 \\
\hline & ChDF & & 16.29 & 13.91 & 7.59 & 8.48 \\
\hline \multirow{2}{*}{96} & $\mathrm{rCh}$ & & & 100.00 & 58.90 & 65.75 \\
\hline & ChDF & & & 18.17 & 9.92 & 11.07 \\
\hline \multirow{2}{*}{108} & $\mathrm{rCh}$ & & & & 66.26 & 73.97 \\
\hline & ChDF & & & & 12.55 & 14.02 \\
\hline \multirow{2}{*}{120} & $\mathrm{rCh}$ & & & & 73.62 & 82.19 \\
\hline & ChDF & & & & 15.50 & 17.30 \\
\hline
\end{tabular}




\begin{tabular}{cccc}
\hline \multirow{2}{*}{132} & rCh & 80.98 & 90.41 \\
& ChDF & 18.75 & 20.94 \\
144 & rCh & 88.34 & 98.63 \\
& ChDF & 22.32 & 24.92 \\
156 & rCh & 95.71 & 100.00 \\
& ChDF & 26.19 & 29.24 \\
168 & rCh & 100.00 & 30.38 \\
\hline
\end{tabular}

Table 3. Relative Charge and Charge Deterioration Factors for 30mm Cover

\begin{tabular}{|c|c|c|c|c|c|c|}
\hline \multirow{2}{*}{ Test duration } & \multirow{2}{*}{$\begin{array}{l}\text { Corrosion } \\
\text { indicators }\end{array}$} & \multicolumn{5}{|c|}{ Relative Charge $(\mathrm{rCh})$ and Charge Deterioration Factors $(\mathrm{ChDF})$ for $30 \mathrm{~mm}$ effective cover } \\
\hline & & $\mathrm{B} 1$ & B2 & B3 & B4 & B5 \\
\hline \multirow{2}{*}{0} & $\mathrm{rCh}$ & 0.00 & 0.00 & 0.00 & 0.00 & 0.00 \\
\hline & ChDF & 0.00 & 0.00 & 0.00 & 0.00 & 0.00 \\
\hline \multirow{2}{*}{12} & $\mathrm{rCh}$ & 10.81 & 8.05 & 6.67 & 4.41 & 5.17 \\
\hline & $\mathrm{ChDF}$ & 0.23 & 0.17 & 0.14 & 0.09 & 0.11 \\
\hline \multirow{2}{*}{24} & $\mathrm{rCh}$ & 21.62 & 16.11 & 13.33 & 8.82 & 10.34 \\
\hline & ChDF & 0.91 & 0.68 & 0.56 & 0.37 & 0.44 \\
\hline \multirow{2}{*}{36} & $\mathrm{rCh}$ & 32.43 & 24.16 & 20.00 & 13.24 & 15.52 \\
\hline & $\mathrm{ChDF}$ & 2.05 & 1.53 & 1.26 & 0.84 & 0.98 \\
\hline \multirow{2}{*}{48} & $\mathrm{rCh}$ & 43.24 & 32.21 & 26.67 & 17.65 & 20.69 \\
\hline & $\mathrm{ChDF}$ & 3.64 & 2.71 & 2.25 & 1.49 & 1.74 \\
\hline \multirow{2}{*}{60} & $\mathrm{rCh}$ & 54.05 & 40.27 & 33.33 & 22.06 & 25.86 \\
\hline & $\mathrm{ChDF}$ & 5.69 & 4.24 & 3.51 & 2.32 & 2.72 \\
\hline \multirow{2}{*}{72} & $\mathrm{rCh}$ & 64.86 & 48.32 & 40.00 & 26.47 & 31.03 \\
\hline & $\mathrm{ChDF}$ & 8.19 & 6.10 & 5.05 & 3.34 & 3.92 \\
\hline \multirow{2}{*}{84} & $\mathrm{rCh}$ & 75.68 & 56.38 & 46.67 & 30.88 & 36.21 \\
\hline & $\mathrm{ChDF}$ & 11.15 & 8.31 & 6.88 & 4.55 & 5.34 \\
\hline \multirow{2}{*}{96} & $\mathrm{rCh}$ & 86.49 & 64.43 & 53.33 & 35.29 & 41.38 \\
\hline & ChDF & 14.57 & 10.85 & 8.98 & 5.94 & 6.97 \\
\hline \multirow{2}{*}{108} & $\mathrm{rCh}$ & 97.30 & 72.48 & 60.00 & 39.71 & 46.55 \\
\hline & $\mathrm{ChDF}$ & 18.44 & 13.73 & 11.37 & 7.52 & 8.82 \\
\hline \multirow{2}{*}{120} & $\mathrm{rCh}$ & 100.00 & 80.54 & 66.67 & 44.12 & 51.72 \\
\hline & $\mathrm{ChDF}$ & 22.76 & 16.96 & 14.04 & 9.29 & 10.89 \\
\hline \multirow{2}{*}{132} & $\mathrm{rCh}$ & & 88.59 & 73.33 & 48.53 & 56.90 \\
\hline & $\mathrm{ChDF}$ & & 20.52 & 16.98 & 11.24 & 13.18 \\
\hline \multirow{2}{*}{144} & $\mathrm{rCh}$ & & 96.64 & 80.00 & 52.94 & 62.07 \\
\hline & $\mathrm{ChDF}$ & & 24.42 & 20.21 & 13.37 & 15.68 \\
\hline \multirow{2}{*}{156} & $\mathrm{rCh}$ & & 100.00 & 86.67 & 57.35 & 67.24 \\
\hline & ChDF & & 28.65 & 23.72 & 15.70 & 18.40 \\
\hline \multirow{2}{*}{168} & $\mathrm{rCh}$ & & & 93.33 & 61.76 & 72.41 \\
\hline & $\mathrm{ChDF}$ & & & 27.51 & 18.20 & 21.34 \\
\hline \multirow{2}{*}{180} & $\mathrm{rCh}$ & & & 100.00 & 66.18 & 77.59 \\
\hline & ChDF & & & 31.58 & 20.90 & 24.50 \\
\hline \multirow{2}{*}{192} & $\mathrm{rCh}$ & & & & 70.59 & 82.76 \\
\hline & ChDF & & & & 23.78 & 27.88 \\
\hline \multirow{2}{*}{204} & $\mathrm{rCh}$ & & & & 75.00 & 87.93 \\
\hline & $\mathrm{ChDF}$ & & & & 26.84 & 31.47 \\
\hline 216 & $\mathrm{rCh}$ & & & & 79.41 & 93.10 \\
\hline 216 & ChDF & & & & 30.09 & 35.28 \\
\hline & $\mathrm{rCh}$ & & & & 83.82 & 98.28 \\
\hline 228 & $\mathrm{ChDF}$ & & & & 33.53 & 39.31 \\
\hline & $\mathrm{rCh}$ & & & & 88.24 & 100.00 \\
\hline 240 & ChDF & & & & 37.15 & 43.56 \\
\hline 252 & $\mathrm{rCh}$ & & & & 92.65 & \\
\hline 252 & $\mathrm{ChDF}$ & & & & 40.96 & \\
\hline & $\mathrm{rCh}$ & & & & 97.06 & \\
\hline 264 & $\mathrm{ChDF}$ & & & & 44.95 & \\
\hline 276 & $\mathrm{rCh}$ & & & & 100.00 & \\
\hline
\end{tabular}


Table 4. Relative Charge and Charge Deterioration Factors for 40mm Cover

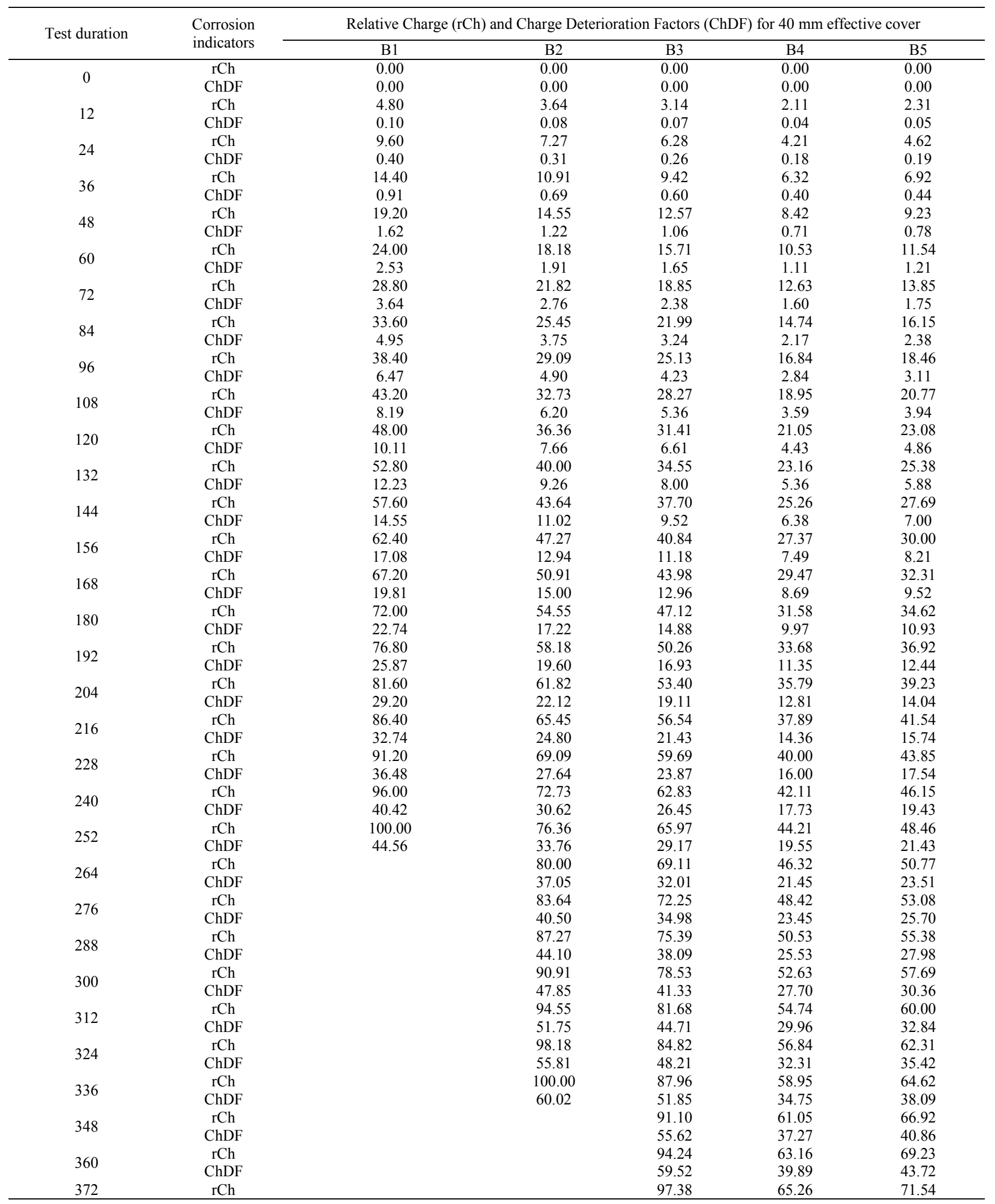




\begin{tabular}{|c|c|c|c|c|}
\hline & $\mathrm{ChDF}$ & 63.55 & 42.59 & 46.69 \\
\hline \multirow{2}{*}{384} & $\mathrm{rCh}$ & 100.00 & 67.37 & 73.85 \\
\hline & $\mathrm{ChDF}$ & 67.72 & 45.39 & 49.75 \\
\hline \multirow{2}{*}{396} & $\mathrm{rCh}$ & & 69.47 & 76.15 \\
\hline & $\mathrm{ChDF}$ & & 48.27 & 52.91 \\
\hline \multirow{2}{*}{408} & $\mathrm{rCh}$ & & 71.58 & 78.46 \\
\hline & $\mathrm{ChDF}$ & & 51.24 & 56.16 \\
\hline \multirow{2}{*}{420} & $\mathrm{rCh}$ & & 73.68 & 80.77 \\
\hline & $\mathrm{ChDF}$ & & 54.29 & 59.51 \\
\hline \multirow{3}{*}{432} & $\mathrm{rCh}$ & & 75.79 & 83.08 \\
\hline & $\mathrm{ChDF}$ & & 57.44 & 62.96 \\
\hline & $\mathrm{rCh}$ & & 77.89 & 85.38 \\
\hline 444 & $\mathrm{ChDF}$ & & 60.68 & 66.51 \\
\hline \multirow[b]{2}{*}{456} & $\mathrm{rCh}$ & & 80.00 & 87.69 \\
\hline & $\mathrm{ChDF}$ & & 64.00 & 70.15 \\
\hline \multirow{2}{*}{468} & $\mathrm{rCh}$ & & 82.11 & 90.00 \\
\hline & $\mathrm{ChDF}$ & & 67.41 & 73.89 \\
\hline \multirow{2}{*}{480} & $\mathrm{rCh}$ & & 84.21 & 92.31 \\
\hline & $\mathrm{ChDF}$ & & 70.91 & 77.73 \\
\hline \multirow{2}{*}{492} & $\mathrm{rCh}$ & & 86.32 & 94.62 \\
\hline & $\mathrm{ChDF}$ & & 74.50 & 81.67 \\
\hline \multirow{2}{*}{504} & $\mathrm{rCh}$ & & 88.42 & 96.92 \\
\hline & $\mathrm{ChDF}$ & & 78.18 & 85.70 \\
\hline \multirow{2}{*}{516} & $\mathrm{rCh}$ & & 90.53 & 99.23 \\
\hline & $\mathrm{ChDF}$ & & 81.95 & 89.83 \\
\hline \multirow{2}{*}{528} & $\mathrm{rCh}$ & & 92.63 & 100.00 \\
\hline & $\mathrm{ChDF}$ & & 85.81 & 94.06 \\
\hline \multirow{2}{*}{540} & $\mathrm{rCh}$ & & 94.74 & \\
\hline & $\mathrm{ChDF}$ & & 89.75 & \\
\hline \multirow{2}{*}{552} & $\mathrm{rCh}$ & & 96.84 & \\
\hline & $\mathrm{ChDF}$ & & 93.78 & \\
\hline \multirow{2}{*}{564} & $\mathrm{rCh}$ & & 98.95 & \\
\hline & $\mathrm{ChDF}$ & & 97.91 & \\
\hline \multirow{2}{*}{576} & $\mathrm{rCh}$ & & 100.00 & \\
\hline & $\mathrm{ChDF}$ & & 100.00 & \\
\hline
\end{tabular}

Cracks at concrete cover level indicates the scale of corrosion in the rebars. Occurrence of full crack at concrete cover level along the length of beam confirms 100 percent corrosion in that rebar. Time taken for occurrence of full crack at concrete cover level along the length of beam demonstrates the corrosion inhibitive ability of bacterial concrete beams of various cover thickness. From the test results $10^{5}$ cell concentration of bacterial concrete beams fared well in protecting the steel reinforcement in concrete. At any instant of test duration, charge passed through reinforced bacterial concrete beams is less than normal reinforced beams where no bacteria is used. This indicates that flow of electrons is less in bacterial concrete beams so is the rate of corrosion. More charge passed indicates more passage of electrons so is the more probability of corrosion. Time taken for $100 \%$ passage of charge through rebars in concrete beams incorporated with optimum cell concentration of bacteria is more compared to normal beams which means bacterial concrete beams will take more time to corrode. Reinforced concrete beams admixed with optimum cell concentration took relatively more time to allow $100 \%$ charge pass through it for also cover thicknesses considered. So possible inception of corrosion in bacteria incorporated reinforced concrete beams is very low when compared to normal beams.

At any instant of test duration, Charge deterioration factors will indicate the magnitude of deterioration caused due to corrosion in the beams. Charge deterioration factors will be more in normal reinforced beams. Reinforced bacterial concrete beams has less charge deterioration factors at all cover thicknesses considered. This may be due to dense microstructure of bacteria induced concrete.

\section{Conclusions}

1. The time of total charge passing till full crack failure for different effective covers considered is more for bacterial concrete than the normal concrete. This increase in total time for full crack to occur is observed in $10^{5}$ bacterial cell concentration incorporated beams.

2. The time of total charge passing at failure in bacterial concrete is more because beam specimens did not develop any fissures or micro cracks as they did not expand when immersed in natural sea water due to calcite precipitation layer on the surface of beams.

3. The "Charge Deterioration Factors" at any given time of full crack failure for different effective covers considered is less for bacterial concrete than the normal concrete.

It is concluded that that bacterial concrete will have the higher life compared to normal concrete. Bacterial concrete will have high life than the normal concrete because calcite precipitate crystals impermeable the concrete specimens and resists the harmful solutions into the concrete there by decreasing the deleterious effects they may cause. 


\section{References}

1. 'Diagnosis and Assessment of Concrete Structures'-State of the Art Report; CEB Bulletin d'information N. 192; International Federation for Structural Concrete (FIB): Lausanne, Switzerland, January 1989.

2. R Polder, C Andrade, B Elsener, J Gulikers, R Weidert, M Raupach, 'Recommendations of RILEM TC 154-EMC: Electrochemical techniques for measuring metallic corrosion. Test method for onsite measurement of resistivity of concrete. Mater. Struct. 2003, 36, 461-471

3. Srinivasa Rao D, Sandhya Rani MN, Sarfaraz Nawa z Syed and Suresh Kumar Tummala, E3S Web of Conferences 8701003 (2019)

4. Sateesh, N., Sampath Rao, P., Ravishanker, D.V., Satyanarayana, K (2015). 'Effect of Moisture on GFRP Composite Materials (2015) Materials Today: Proceedings, 2 (4-5), pp. 2902-2908

5. Devi, G.N., Saranya, J., Manjubaashini, N., Thangadurai, T.D., Roopan, S.M., Chitra, S (2017), 'Polyamidoaminoepichlorohydrin resin a novel synthetic anti-corrosive water soluble polymer for mild steel', Progress in Organic Coatings, 109, pp. 117-125.

6. Bankupalli, P.T., Srikanth Babu, V., Suresh Kumar. $\mathrm{T}$, International Journal of Applied Engineering Research, 10(16), pp. 37057-37062, 2015

7. T.srinivas and M.Abinay Raj (2019), "Seismic Effect on Design of Residential Multi-Storey Building (Stilt+17 Floors) in Zone-III and Zone-IV using Etabs", International Journal of Engineering and Advanced Technology (IJEAT), ISSN: 2249 - 8958, Volume-8, Issue-6, August 2019, pp 4662-4666. 